ISSN 1991-8631

Original Paper

http://indexmedicus.afro.who.int

\title{
Analgesic and anti-inflammatory activities of the saponins extract of Carissa edulis root in rodents
}

\author{
Halimatu Sadiya HASSAN ${ }^{1 *}$, Muhammad Ibrahim SULE ${ }^{1}$, Muhammad Aliyu MUSA ${ }^{1}$, \\ Andrew Akyah EMMANUEL ${ }^{1}$, Hajara IBRAHIM ${ }^{2}$, Ali Sanusi HASSAN ${ }^{3}$ and \\ Abdullahi Hamza YARO ${ }^{4}$ \\ ${ }^{I}$ Department of Pharmaceutical and Medicinal Chemistry, Ahmadu Bello University, Zaria, Nigeria. \\ ${ }^{2}$ Department of Pharmacognosy and Drug Development, Ahmadu Bello University, Zaria, Nigeria. \\ ${ }^{3}$ Department of Biological Sciences, Kaduna State University, Kaduna, Nigeria. \\ ${ }^{4}$ Department of Pharmacology, Faculty of Medicine, Bayero University, Kano, Nigeria. \\ *Corresponding author, E-mail: hlmtsdyhassan@yahoo.com, Tel: (+234) 0854526909
}

\begin{abstract}
The saponins extract of Carissa edulis Vahl family Apocynaceae was investigated for analgesic and anti-inflammatory activities. The analgesic activity was studied using hot-plate and acetic acid-induced writhing tests in mice while the anti-inflammatory activity was studied using carrageenan-induced paw oedema test in rats. The saponins extract at all the doses tested showed statistically significant analgesic activity $(\mathrm{P}<0.001)$ in the two models used for the study and the results were comparable to those obtained with the standard drugs used in each case. The saponins extract also showed significant anti-inflammatory activity $(\mathrm{P}<0.001)$ at all the doses used in the study. The inhibition of oedema produced by the extract was comparable to the inhibition produced by $10 \mathrm{mg} / \mathrm{kg}$ ketoprofen. The saponins extract was found to have an intraperitoneal $\mathrm{LD}_{50}$ of 565.69 $\mathrm{mg} / \mathrm{kg}$ indicating a moderate toxicity. The thin layer chromatographic analysis showed the presence of triterpenoid saponins. The study showed that the saponins extract of Carissa edulis root has potential analgesic and anti-inflammatory properties.
\end{abstract}

() 2010 International Formulae Group. All rights reserved.

Keywords: Carissa edulis, triterpenoid saponins, analgesic activity, anti-inflammatory activity.

\section{INTRODUCTION}

Carissa edulis Vahl (Apocynaceae) is a spiny shrub that grows up to $5 \mathrm{~m}$ high. The plant is indigenous to tropical Africa and Asia. The root is used to treat glandular inflammation, lumbago and other pains (Burkill, 1985). Various parts of the plant are used in traditional medicine for the treatment of fever, oedema, toothache, cough, ulcer, sickle cell anaemia and hernia (Oliver, 1960; Sofowora, 1982). The plant is called "Bagozaki" or "Ciizaakii" in Hausa. The analgesic activity of the water extracts of the various parts of the plant has been studied. In 
the study, analgesic activity was attributed partially to its methylsalicylate content (Ibrahim et al., 2007). Coumarins, sesquiterpenes, lignans, benzenoids and quinoids have been isolated from the roots of the plant (Achenbach et al., 1983; 1985).

Saponins constitute a class of natural products, which are structurally constructed of an aglycone that may be triterpene, steroid or steroidal alkaloid and a sugar moiety [usually pentose(s), hexose(s) and/or uronic acid(s)]. The aglycone or non-saccharide portion of the saponin molecule is called the genin or sapogenin. Depending upon the type of genin present, saponins can be divided into three major classes: (1) triterpene glycosides, (2) steroid glycosides, and (3) steroidal alkaloid glycosides (Mahato et al., 1982). Numerous biological activities are associated with saponins, such as analgesic, antiinflammatory, anticancer, haemolytic, antimicrobial, antibacterial, antiviral, molluscicidal, insecticidal, diuretic, sedative and cholesterol lowering activities (LacailleDubois and Wagner, 1996). Consequently, great interest has been shown in their characterization and in the investigation of their pharmacological and biological properties. This study aims at investigating the analgesic and anti-inflammatory activities of the saponins extract of the root of Carissa edulis which to our knowledge has not been reported.

\section{MATERIALS AND METHODS}

\section{Plant materials}

The plant sample of Carissa edulis were collected from Panhauya village near Samaru, Zaria in the month of October, 2008. It was identified and authenticated in the Herbarium of the Department of Biological Sciences, Ahmadu Bello University, Zaria where a voucher specimen number 900132 has been deposited. The roots were separated, air-dried and powdered using mortar and pestle.

\section{Extraction procedures}

The powdered root material $(150 \mathrm{~g})$ was extracted exhaustively with aqueous ethanol $(70 \%)$. The extract obtained was concentrated under reduced pressure, suspended in distilled water and partitioned with ethylacetate, then n-butanol. The nbutanol fraction was further partitioned with $1 \%$ potassium hydroxide to remove polyphenolic compounds such as flavonoids and tannins (Woo et al., 1980). The n-butanol extract that was obtained from the above partitioning procedures was then evaporated under reduced pressure to give saponins residue (RCE) weighing $2.8 \mathrm{~g}$.

\section{Test for saponins}

The saponins extract was subjected to froth and haemolysis tests (Brain and Turner, 1975).

\section{Thin-layer Chromatography}

Thin-layer chromatographic analysis of the saponins extract was carried out using the method of Stahl, 1965. The solvent system used was chloroform/methanol in a ratio of 1:1. The developed plates were visualized using Liebermann-Burchard spray reagent and heating at $100^{\circ} \mathrm{C}$ for 10 minutes.

\section{Test animals}

Swiss albino mice weighing 17-27 g and Wister rats weighing 150-200 $\mathrm{g}$ of both sexes were used for the study. The animals were obtained from the Animal House Facility of the Department of Pharmacology and Therapeutics, Ahmadu Bello University, Zaria, Nigeria. The animals were housed in clean animal cages and given standard animal feeds (Grower' mash: Sander's Feed Ltd, Kaduna) and clean water ad libitum according 
to standard ethics guiding the handling of laboratory animals. Prior to the experiment, the animals were deprived of food for $24 \mathrm{~h}$ but allowed free access to water.

\section{Drugs and dosages}

The following drugs were used: Ketoprofen (Lek, Yogaslavia: $10 \mathrm{mg} / \mathrm{kg}$ ), $0.6 \%$ acetic acid solution (Searle Essex: $10 \mathrm{ml} / \mathrm{kg}$ ), $1 \%$ suspension of carrageenan (Sigma: $0.5 \mathrm{ml} /$ animal), saponin extract of Carissa edulis (RCE), vehicle (Normal Saline: - DANA, Nigeria: $10 \mathrm{ml} / \mathrm{kg}$ ). All test solutions were administered intraperitoneally.

\section{Acute toxicity study}

This was carried out to determined the $\mathrm{LD}_{50}$ using the method described by Lorke (1983). In the first phase, nine mice divided into three groups of three mice each were administered the saponins extract at doses of 10, 100, $1000 \mathrm{mg} / \mathrm{kg}$ body weight intraperitoneally respectively. The animals receiving $1000 \mathrm{mg} / \mathrm{kg}$ all died and thus the second phase involved four groups of one animal each which were treated with 200, 400, 800 and $1600 \mathrm{mg} / \mathrm{kg}$ body weight respectively of the saponins extract. Signs of toxicity and lethality were observed for 24 hours. The $\mathrm{LD}_{50}$ was calculated as the geometric mean of the lowest lethal dose that caused death and the highest non-lethal dose that did not cause death $(0 / 1$ and $1 / 1)$.

\section{Hot-plate test}

This was carried out to measure the response latencies according to the method described by Eddy and Leimback (1953). A hot plate (Gallenkamp thermostat) was maintain at $55 \pm 0.5^{\circ} \mathrm{C}$ and the experimental animals were placed individually on it, the time interval from placement and shaking/licking of the paw or jumping off the hot plate was recorded as an index of response latency. Five groups of six mice each were used for control, standard and extract treated groups. Groups 1 and 2 received normal saline $(10 \mathrm{ml} / \mathrm{kg})$ and morphine (5 $\mathrm{mg} / \mathrm{kg}$ ) respectively while groups 3,4 and 5 received extract at doses of 150,75 and 37.5 $\mathrm{mg} / \mathrm{kg}$ body weight respectively. Thirty minutes after treatment, the mice were placed individually on the heated plate and response latencies or pain reaction time in seconds were noted and recorded.

\section{Acetic acid-induced abdominal writhing test}

This was carried out according to the method of Koster et al. (1959). Five groups containing six mice each were administered with ketoprofen $(10 \mathrm{mg} / \mathrm{kg})$, saponins extract of $C$. edulis 37.5, 75 and $150 \mathrm{mg} / \mathrm{kg}$ body weight respectively while mice in the fifth group were given normal saline. Thirty minutes after treatment, each animal was given acetic acid (10 ml/kg body weight ip). The number of writhing responses was recorded for each animal after 5 minutes latency interval using tally counter for the period of 10 minutes. The percentage inhibition of the abdominal constrictions or writhes was calculated using the following formula:

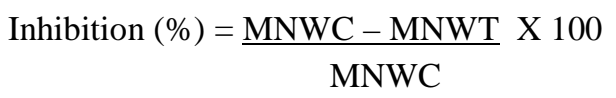

MNWC=Mean No. of Writhes (Control); MNWT=Mean No. of Writhes (Test).

\section{Carrageenan-induced paw oedema test}

The study was carried out according to the method descried by Winter et al. (1962). The rats were divided into five groups containing six animals each and pretreated with the extract $(37.5,75,150 \mathrm{mg} / \mathrm{kg}$ body weight), ketoprofen (10 mg/kg body weight) 
as positive control and normal saline (10 $\mathrm{ml} / \mathrm{kg}$ body weight) respectively to each group. After 30 minutes, $0.1 \mathrm{ml}$ of freshly prepared carrageenan suspension $(1 \% \mathrm{w} / \mathrm{v}$ in normal saline) was injected into the subplanter region of the left hind paw of each rat. The paw diameter was measured with the aid of varnier caliper at $0,1,2,3$ and 4 hours after injection of the carrageenan.

\section{Statistical analysis}

The data were expressed as mean \pm SEM and analyzed using one way ANOVA followed by post-hoc Scheffe test for multiple comparison. $\mathrm{P}$ values less than $0.05(\mathrm{P}<0.05)$ were considered to be statistically significant.

\section{RESULTS}

The procedure used in the extraction of saponins from the roots of $C$. edulis gave a percentage yield of $1.87 \%$. The extract tested positive to the froth and haemolysis tests. The thin-layer chromatography (TLC) of the extract showed a major spot with $\mathrm{R}_{\mathrm{F}}$ value of 0.63 and three minor spots with $\mathrm{R}_{\mathrm{F}}$ values ranging from 0.05-0.28 (Table 1). The spots were coloured reddish brown to purple with Liebermann-Burchard spray reagent. The intraperitoneal $\mathrm{LD}_{50}$ of the extract was determined to be $565.69 \mathrm{mg} / \mathrm{kg}$. The analgesic activities of RCE at test doses ranged from $8.050 \pm 0.946$ to $21.250 \pm 2.957$ mean time in seconds taken to respond in the hot plate test and $5.500 \pm 0.922$ to $2.833 \pm 0.909$ mean number of writhing in the acetic acid-induced writhing test which were statistically significant $(\mathrm{P}<0.001)$ when subjected to statistical analysis as shown in Tables 2 and 3 respectively. The extract showed statistically significant activities $(\mathrm{P}<0.001)$ at all the doses used in the carrageenan-induced paw oedema test (Table 4). The saponins extract at the doses used produced $75-80 \%$ inhibition of oedema at three hours of oedema (Figure 1). The anti-inflammatory results of RCE were comparable with $10 \mathrm{mg} / \mathrm{kg}$ ketoprofen.

Table 1: TLC of saponins extract of Carissa edulis root.

\begin{tabular}{lll}
\hline Spots & $\mathbf{R}_{\mathbf{F}}$ Value & Colour of spots with L-B \\
\hline 1 & 0.05 & Reddish brown \\
2 & 0.12 & Purple \\
3 & 0.28 & Reddish brown \\
4 & 0.63 & Purple \\
\hline \multicolumn{2}{c}{ L-B = Liebermann-Burchard' Spray Reagent }
\end{tabular}

Table 2: The analgesic activity of RCE using the hot plate test.

\begin{tabular}{ll}
\hline Treatments & Mean time (seconds) \pm SEM \\
\hline Normal saline $10 \mathrm{ml} / \mathrm{kg}$ & $2.062 \pm 0.141$ \\
RCE $37.5 \mathrm{mg} / \mathrm{kg}$ & $8.050 \pm 0.946^{*}$ \\
RCE $75 \mathrm{mg} / \mathrm{kg}$ & $9.600 \pm 1.759^{*}$ \\
RCE $150 \mathrm{mg} / \mathrm{kg}$ & $21.250 \pm 2.957^{*}$ \\
Morphine $5 \mathrm{mg} / \mathrm{kg}$ & $7.870 \pm 1.666^{*}$ \\
ONE WAY ANOVA & $\mathrm{df}=4,25 ; \mathrm{F}=30.535 ; \mathrm{P}<0.001$
\end{tabular}

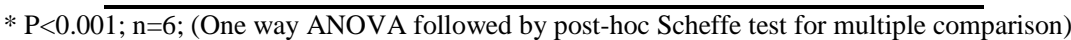
$\mathrm{RCE}=$ saponins extract of Carissa edulis root, $\mathrm{df}=$ degree of freedom, $\mathrm{F}=$ factor, $\mathrm{P}=$ probability. 
Table 3: Analgesic activity of RCE using acetic acid-induced writhing test.

\begin{tabular}{llc}
\hline Treatment Groups & $\begin{array}{l}\text { Mean Number of Writhing } \pm \pm \\
\text { SEM }\end{array}$ & $\begin{array}{c}\text { Percentage } \\
\text { Inhibition }\end{array}$ \\
\hline Normal saline $10 \mathrm{ml} / \mathrm{kg}$ & $18.333 \pm 1.358$ & - \\
RCE $37.5 \mathrm{mg} / \mathrm{kg}$ & $5.500 \pm 0.922^{*}$ & 70 \\
RCE $75 \mathrm{mg} / \mathrm{kg}$ & $3.167 \pm 0.477^{*}$ & 83 \\
RCE $150 \mathrm{mg} / \mathrm{kg}$ & $2.833 \pm 0.909^{*}$ & 85 \\
Piroxicam $20 \mathrm{mg} / \mathrm{kg}$ & $8.167 \pm 1.701^{*}$ & 61 \\
ONE WAY ANOVA & $\mathrm{df}=4,25 ; \mathrm{F}=30.535 ; \mathrm{P}<0.001$ \\
\hline *P $<0.001 ; \mathrm{n}=6 ;$ (One way ANOVA followed by post-hoc Scheffe test for multiple comparison) \\
RCE= saponins extract of Carissa edulis root, df= degree of freedom, F= Factor, P= Probability
\end{tabular}

Table 4: Anti-inflammatory activity of RCE using carrageenan-induced paw oedema test.

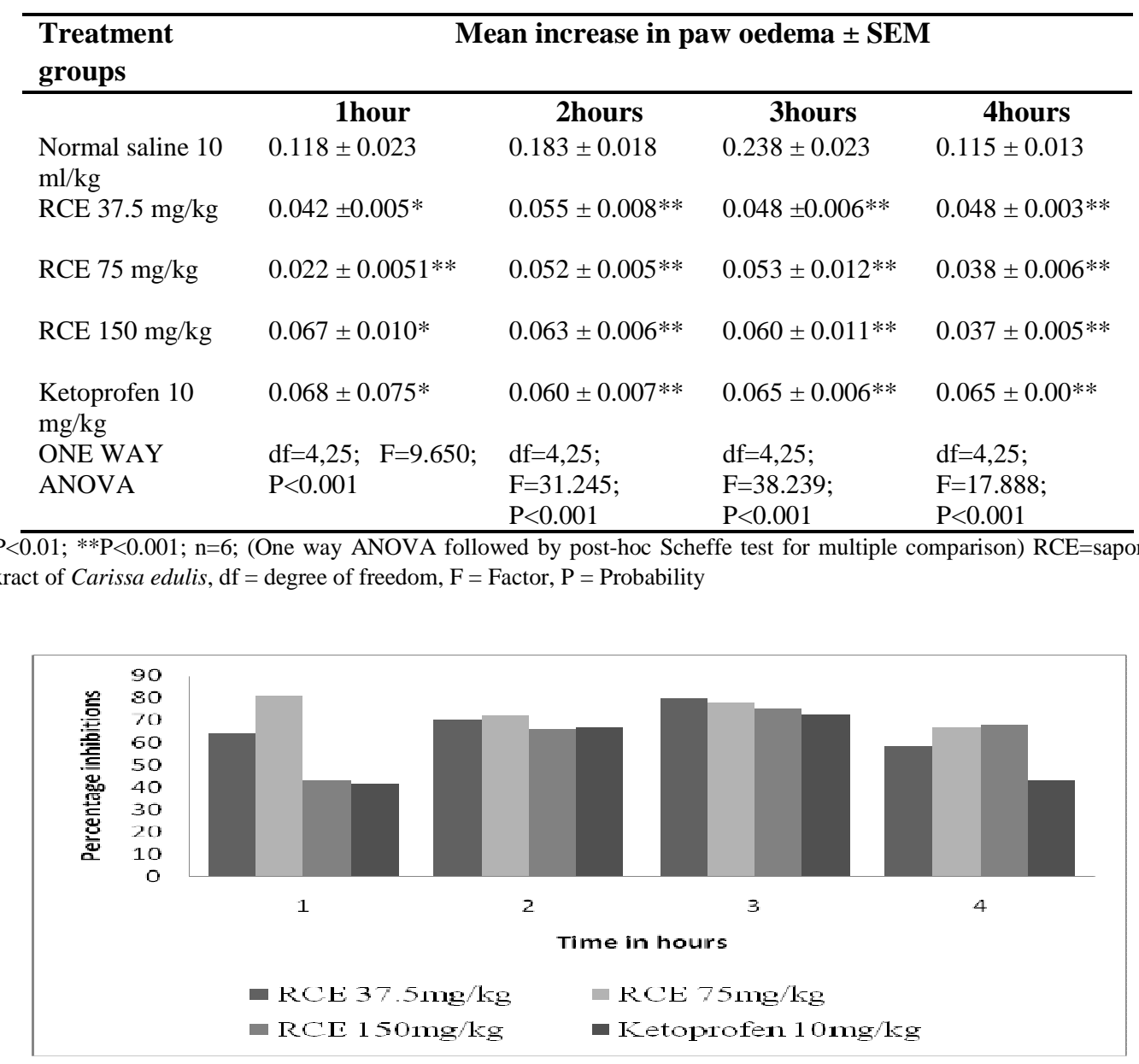

Figure 1: Percentage inhibitions of the saponin extract of $C$. edulis and standard drug ketoprofen in carrageenan-induced rat paw oedema. 


\section{DISCUSSION}

The extraction method used gave $1.87 \%$ yield of crude saponins extract from the root of Carissa edulis which is relatively low when compared to the $10 \%$ total saponins that have been isolated from the bark of Quillaia saponaria (Evans, 1996). The froth and haemolysis tests showed the presence of saponins in the crude extract. TLC of the saponins extract produced four spots coloured reddish brown and purple when sprayed with Liebermann-Burchard sprayed reagent. The reddish brown and purple coloured spots observed are indication of the presence of triterpenoid type of saponins (Chandel and Rastogi, 1980). The TLC of the saponins can serve as a chromatographic finger print that could be used in the standardisation and quality control of saponin extract of $C$. edulis. The acute toxicity study gave an intraperitoneal $\mathrm{LD}_{50}$ of $565.69 \mathrm{mg} / \mathrm{kg}$ showing that the saponins extract is relatively less toxic (Dubois and Geiling, 1959).

The hot plate test is a standard procedure for the evaluation of centrally mediated analgesic activity. Drugs that mediate their analgesic effect through this mechanism are the narcotic analgesic agents like morphine, pentazocine, codeine and pethidine (Laurence et al., 1999). The group treated with saponins extract showed significant increase in mean reaction time and thus the saponins extract of Carissa edulis may be said to possess central analgesic activity similar to the narcotic analgesic agents. The acetic acid-induced writhing test is usually employed to screen for peripheral analgesic activity (Bentley et al., 1981). Intraperitoneal administration of acetic acid to mice leads to the release of prostaglandins like $\mathrm{PGE}_{2}$ and $\mathrm{PGF}_{2} \alpha$ (Besra et al., 1996) which have been implicated as mediators of pains and inflammations. Drugs with analgesic activity similar to the nonsteroidal anti-inflammatory agents such as aspirin and it derivatives are usually detected using this method (Brignola, et al., 1994). The analgesic activity of the saponins extract of Carissa edulis root may be by the inhibition of both central and peripheral pain mediators.

The carrageenan-induced inflammatory reaction is bi-phasic in nature. The first phase is due to the release of histamine, serotonin and kinins in the first hour while the second phase that lasted for 2 to 3 hours is attributed to the release of prostaglandins and lysosomal enzymes (DiRosa et al., 1971). Significant inhibitory activity was elicited by the saponins extract at all the hours of inflammation which may be due to its ability to inhibit the release of the mediators of inflammation. The triterpenoid saponins isolated from different plants such as Bupleurum falcatum, Phytolacca americana and Madhuca longifolia have been shown to have significant analgesic and anti-inflammatory activities (Chandel and Rastogi, 1980; Singh et al., 1992). The saponins from ivy (Hedera helix and $H$. colchica) have been reported to exert their anti-inflammatory effects by blocking bradykinin and other inflammatory mediators such as the prostaglandins (Gepdiremen et al., 2005). Therefore, the analgesic and antiinflammatory activities of Carissa edulis may be due in part or mainly to it saponins content. This study has shown that the saponins of Carissa edulis root have potential analgesic and anti-inflammatory properties and can be utilized for therapeutic purposes.

\section{ACKNOWLEDGEMENTS}

The authors acknowledged University Board of Research, Ahmadu Bello 
University, Zaria for the award of research grant that helped in carrying out this study.

\section{REFERENCES}

Achenbach H, Waibel R, Addea-SMensah I. 1983. Constituents of West African medicinal plants. 12 Lignans and other constituents from Carissa edulis. Phytochemistry, 22(3): 749-753.

Achenbach H, Waibel R. Addea-Mensah I. 1985. Sesquiterpenes from Carissa edulis. Phytochemistry, 24(10): 23252328.

Bentley GA, Newton SH, Starr J. 1981. Evidence for an action of morphine and enkaphalins on sensory nerve endings in the mouse peritoneum. British Journal of Pharmacology, 73: 325-332.

Besra SE, Sharma RM, Gomes A. 1996. Anti-inflammatory effect of petroleum ether extract of the leaves of Litchi chinensis Gaertn (Sapindaceae). Journal of Ethnopharmacology, 54: 1-6.

Brain KR, Turner TO. 1975. The Practical Evaluation of Phytopharmaceuticals. Wright-Scientechnica: Bristol, UK; 50154.

Brignola G, Calignano A, DiRosa M. 1994. Modulation of morphine antinociception in the mouse by endogenous nitric oxide. British Journal of Pharmacology, 113: 1372-1376.

Burkill HM. 1985. The Useful Plants of West Tropical Africa (Volume 1). Royal Botanical Gardens, Kew; 145-146.

Chandel RS, Rastogi RP. 1980. Review: Triterpenoid saponins and sapogenins Phytochemistry, 19: 1889-1908.

DiRosa M, Givoud JP, Willonghby DA. 1971. Studies of the mediators of acute inflammatory response induced rats in different sites by carrageenan and turpentine. Journal of Pathology, 104: 15-29.

Dubois HP, Geiling EMH. 1959. Textbook of Toxicology. University Press: London, UK; 302-303.

Eddy NB, Leimback D. 1953. Synthetic analgesics II: Dithienylbutenyl and dithenbutylamines. Journal of Pharmacology Experimental and Therapeutics, 107: 385-393.

Evans WC. 1996. Trease and Evans' Pharmacognosy $\quad\left(14^{\text {th }}\right.$ edn $)$ WB Saunders Company Ltd: UK; 293-321.

Gepdiremen A, Mshvildadze V, Suleyman, H, Elias R. 2005. Acute antiinflammatory activity of four saponins isolated from ivy: $\alpha$-hederin, hederasaponin-C, hederacolchiside-E and hederacolchiside-F in carrageenaninduced rat paw edema. Phytomedicine, 2(6): 440-444.

Ibrahim H, Abdulrahman EM, Shok M, Ilyas N, Musa KY, Ukandu I. 2007. Comparative analgesic activity of the root bark, stem bark, leaves, fruits and Seeds of Carissa edulis Vahl (Apocynaceae). African Journal of Biotechnology, 6(10): 1233-1235.

Koster R, Anderson M. DeBeer EJ. 1959. Acetic acid for analgesic screening. Federation Proceedings, 18: 412.

Lacaille-Dubois MA, Wagner H. 1996. A review of the biological and pharmacological activities of saponins. Phytomedicines, 2(4): 363-386.

Laurence DR, Bennet PN, Brown MJ. 1999. Clinical Pharmacology. Churchill Livingstone: London; 299-309.

Lorke D. 1983. A new approach to acute toxicity testing. Archives of Toxicology, 54: 275-287. 
Oliver B. 1960. Medicinal Plants in Nigeria. Nigerian College of Arts, Sci. Technol: Ibadan, Nigeria; 52.

Mahato SB, Ganguly AN, Sahu NP. 1982. Steroid Saponins. Phytochemistry, 12(5): 959-978.

Singh GB, Singh S, Bani S, Gupta BD, Banerjee SK. 1992. Anti-inflammatory activities of oleanolic acid in rats and mice. Journal Pharmacy and Pharmacology, 44: 456-458.

Sofowora A. 1982. Medicinal Plants and Traditional Medicine in Africa. John Wiley and Sons Ltd: Chichester: New York, USA; 5-100.
Stahl E. 1969. Thin Layer Chromatoghraphy: A Laboratory Handbook ( $2^{\text {nd }}$ edn). George Allen and Unwin Limited: London; 692-694.

Winter CA, Risley EA, Nuss GW. 1962. Carrageenan-induced oedema in the hind limb paw of the rat as an assay for antiinflammatory drugs. Proceedings of the Society of Experimental Biology and Medicine, 111: 544-547.

Woo SW, Shin HY, Kang KS. 1980. Chemistry and pharmacognosy of flavone-C-glycosides from Ziziphus Seeds. The Korean Journal of Pharmacognosy, 11(3-4): 141-148. 